\title{
Does Customer Retention Strategies Matter in the South African Cellphone Industry?
}

\author{
Motshedisi Elizabeth Molapo
}

Department of Business Management, University of the Free State, QwaQwa Campus, Private Bag X 13, Phuthaditjhaba: South Africa.

Email: molapome@qwa.ufs.ac.za

Geoffrey Mukwada

Department of Geography, University of the Free State, QwaQwa Campus, Private Bag X 13, Phuthadithaba: South Africa

\section{Doi:10.5901/mjss.2014.v5n23p144}

\begin{abstract}
In recent years, the South African cellphone industry has registered a tremendous rise in number of subscribers, with some networks experiencing more than 30\% increase in subscriptions. This paper explores the strategies that have been employed by cellphone companies in South Africa in order to retain subscribers. While previous research has focused on customer retention strategies that are employed across different service industries this study evaluates the retention strategies that have been adopted by the cellphone industry, where players are battling to retain customers or recruit new ones. The evaluation is based on the perceptions of the customers of five cellphone network providers that operate in South Africa. The paper concludes that though there are many customer retention strategies that are employed in the South African cellphone industry, the most effective are those related to quality of service, affordability of service and provision of customer support services.
\end{abstract}

Keywords: Cellphone industry; Customer satisfaction; Customer retention strategies; Perceived value; South Africa

\section{Introduction}

Today's competitive environment maximizes customer retention probability so as to sustain the company's protection against inroads competition. Customer retention is needed to achieve this goal. Ramakrishnan (2006: 1) defines customer retention as the marketing goal of preventing customers from going to the competitor. Customer retention is the way in which organisations focus their efforts on existing customers in an effort to continue doing business with them (Mostert et al., 2009: 120). However, customer retention can also mean the number of customers who stay with the provider in the course of an established period, such as a year (Dawes, 2009: 232). Customer retention is a key factor in determining the success of businesses today. Fluss (2010: 4) notes that competitors are always on the lookout to steal customers through better deals. Fluss (2010: 5) has observed that annual customer attrition rates range from 7\% in industries that have high exit barriers such as banking and insurance, to almost $40 \%$ in the cellphone phone industry. It can, therefore, be concluded that customers in the cellphone industry keep on switching network providers for better deals (www.g-cem.org).

Customer retention has a direct impact on long term impact value, which is a more profitable avenue for firms that seek to pursue growth and sustainability or those that seek to protect themselves from market shrinkage resulting from a contracting economy (Gee et al., 2008: 7). Supporting this argument, Lombard (2009: 13) notes that today the pressure on companies to retain customers is fuelled by the market where customer acquisition is slow. Customer retention is important when loyalty is decreasing and sales cycles are aggravating the business environment. Under these circumstances, losing an important customer to a competitor would impact significantly on the organisation's profitability and growth.

According to Cohen, Gau, Au Yong \& Choong (2006: 21) customer retention strategies employed within the service sector worldwide indicates that different service industries adopt different customer retention strategies. In the banking industry, for instance in New Zealand, there has been a revaluation of customer retention strategies in order to limit defection through enhancement of professionalism. Research in New Zealand showed that younger customers have a higher tendency of switching banks in search of greater convenience (Cohen et al, 2006: 21). In the case of the USA the customer retention strategies that were adopted by banks have led to new technological innovations, including the 
provision of online banking services (Vatanasombut et al., 2004: 66). Research in the South African fast foods industry has shown similar results. In the South African fast foods industry, customer retention has tended to focus on the evaluation of customer- management relationships as the major strategy for retaining customers (Lombard, 2009: 76).

According to Dhurup \& Surujlal (2008: 21) a wide range of service industries, as highlighted above, evidence from existing literature on this subject suggests that similar research has not been done in most developing countries. This is particularly so with the cellphone industry in South Africa. It is for this reason that the current paper focuses on customer retention strategies that are employed in this industry. There has been a remarkable increase in subscriptions in the South African cellphone industry, with Cell C registering a 34\% increase in subscriptions between 2007 and 2008. Previously, Vodacom and MTN were regarded as the only giants in the cellphone industry, but currently, Cell C is growing twice as fast as the two giant networks. There is a possibility that the $34 \%$ increase that Cell $\mathrm{C}$ has recorded in subscriptions is partly resulting from subscribers who are switching from Vodacom and MTN. Rich (2000: 6) argues that for an organization to be attractive to customers who switch to its products there is always a reason that influences the customer's decision. Customer defection is indirectly seen in some organizations, as customers do not completely withdraw from their relationship with the organization but rather become inactive (Karamura et al., 2005). The purpose of the current study is to investigate the customer retention strategies that different players in the cellphone industry in South Africa employ and evaluate the effectiveness of these strategies. In line with this aim the study seeks to:

- identify the customer retention strategies that are employed by the cellphone network providers in South Africa,

- evaluate the effectiveness of the strategies

- explore the benefits and setbacks associated with different customer retention strategies and determine the impacts of these benefits and setbacks on the South African cellular networks, and

- recommend the best strategies that work for the South African cellular industry

\section{Literature Review}

The remaining part of the paper includes the literature that was reviewed in this study, the methodology that was employed in the study, the results of the study, as well as a discussion. Some recommendations and conclusions are drawn on the customer retention strategies that are pursued by players within the South African cell phone industry.

\subsection{Current Retention Strategies for the Cellphone Industry}

At global level, considerable research has been done on the cellphone industry, especially in countries like Austria, Europe, UK, Spain, Italy, Greece and Pakistan (Blery et al., 2009: 31). However, most of this research has tended to focus on service satisfaction and service quality. For instance, a study that was conducted in Greece, where the mobile cellphone market has reached its mature stage (Blery et al., 2009:30), revealed that service quality perceptions positively influenced behavioural intentions and willingness by customers to recommend cellphone networks to prospective customers. This study also indicated that service quality is an important factor, which contributes to the organisation's ability to retain loyal customers, and thus contributing to improved organizational performance. In addition the study showed that prices were negatively associated with repurchase intentions. The aim of these studies was to investigate whether service quality and perceived price had any influence on customers repurchasing intentions.

Research on customer retention strategies in the Pakistan cellphone industry is arguably more advanced compared to that undertaken elsewhere in the developing world, where only little research has been done on this subject. Pakistan is the only country where intensive research has been conducted around the topic and is considered as the leading country with regard to research on customer retention strategies in the cellphone industry. Studies in Pakistan revealed that between 2003 and 2006 the number of cellphone subscribers in this country increased by 150\%. The number of subscribers rose from 0.6 million in 1995 to over 98 million in 2009, while the cellular franchises increase from 618 to 1748 between 2003 and 2009 (Khan, 2010:164). The study also revealed that the high penetration rate of the cellphone industry in Pakistan has shifted the focus of the mobile industry to network coverage, upgrading of networks, service quality and competitive pricing, thus attracting and retaining customers, in some cases even exceeding customer expectations regarding service quality, and consequently staving competition. A study that was conducted by lqbal et al., (2010: 6) on cellphone services in Pakistan reported that cellphone service providers should keep their promises with customers and provide services that are based on customer perceptions rather than customer satisfaction, as that will lead to high customer loyalty (www.wbiconpro.com). 
A comparative study on churn management in the Pakistani cellphone industry was based on two network providers namely, Ufone and Telenor. The findings of the study showed that Ufone on the one hand depends on customer retention on individual basis and relies mainly on loyalty enhancement programs. The programs are based on provision of incentives such as talkies packages and zero line rent. Telenor on the other hand focuses on customer acquisition and infrastructural development, as well as use of specialized software to track customers' history through outsourced surveys that are conducted periodically to measure service levels and customer perceptions (Jahanzeb \& Jabeen, 2007:10). The main finding of the study is that Ufone outmatched Telenor in implementing effective customer retention strategies.

\section{Research Methodology}

\subsection{Participants and Research Procedure}

This study involved an empirical investigation and relied on primary data that were collected using a set of quantitative and qualitative methods. This two-pronged approach, generally referred to as the mixed method approach or triangulation, involves a combination of qualitative and quantitative research approaches, techniques, methods, language or concepts in a single study (Johnson \& Onwuegbuzie, 2004:17). The research was conducted through street surveys that were conducted on cellphone users who were found in two randomly selected towns in the eastern Free State, namely Phuthaditjahaba and Bethlehem. Computer generated random number tables were used in the selection of the two towns. Though a total of 500 questionnaires were distributed 429 questionnaires were completed and returned.

\subsection{Instrument}

A questionnaire was used to collect the data. The New Dictionary of Social Work (1995:51) defines a questionnaire as a set of questions on a form that are to be completed by respondents in respect of a research project. In this study, a questionnaire was used due to its cost effectiveness, and also due to the fact that it is easy to analyze. The added advantage was that most respondents were already familiar with questionnaire surveys. This is because in South Africa, the collection of household census data is done through such surveys. In addition a questionnaire offers respondents greater anonymity, thus encouraging respondents to disclose their true feelings and attitudes more readily. It also reduces bias questionnaires.

Fieldworkers were hired to collect the data from cellphone users of all age and racial groups, as well as socioeconomic backgrounds. The aim was to target all cellphone users, regardless of their demographic characteristics. Prior to the survey fieldworkers were trained on how to use the questionnaire. A pre-test survey was done to check whether the field workers were clear on how the questionnaire should be completed. The ethical issues that were considered in this study include informed consent and prevention of violation of the privacy of respondents. Accordingly, respondents were informed of their right to voluntary participation, the objectives of the study, as well as the procedures of filling in the questionnaires. Hakim (2000: 143) advises that informed consent is a necessary condition rather than a luxury or an impediment. Strict confidentiality was assured by maintaining the anonymity of the respondents.

\subsection{Data Analysis}

Statistical Package for Social Scientists (SPSS), version 17.0, was used for data analysis. Kerlinger (1986: 223) defines analysis as categorizing, ordering, manipulating and summarizing data to obtain answers to the research questions. Kerlinger (1986) further explained the purpose of analysis as the reduction of data to an intelligible and interpretable form so that the relations of research problems can be studied and tested and conclusions drawn from the data. SPSS, in particular ANOVA and the calculation of frequency values, provided the best way of doing this. In addition, some of the data was analysed qualitatively as the questionnaire that was used also contained open ended questions.

\section{Findings and Discussion}

Results from this study indicate that most of the cellphone users are young people in their mid-twenties, with $51.2 \%$ of them being females. The study reveals that most of the cellphone customers are on prepaid rather than contract accounts. Only $14.6 \%$ of the respondents are employed. The other important issue that has been revealed by this study is that most respondents use MTN (50.1\%) followed by Vodacom (35.9\%). Respondents cited a number of benefits that they get from their networks. The number and percentages of the respondents who cited these benefits are shown in Table 1. 
Table 1: The number and percentages of respondents who derive benefits from their cellphone network providers

\begin{tabular}{lcc}
\hline Type of benefit & Number of respondents & $\%$ of total \\
\hline Cellphone banking & 218 & 46.1 \\
Talking points & 258 & 54.6 \\
Bulk purchases & 90 & 19.0 \\
Callbacks & 167 & 35.3 \\
Balance checks & 132 & 27.9 \\
Airtime easily available & 139 & 29.4 \\
\hline
\end{tabular}

$\mathrm{N}=429$

As shown in Table 1, with the exception of talking points, the number of respondents who benefit from their networks is less than $50 \%$. This suggests that the majority of respondents do not consider cellphone banking, bulk purchases, callbacks, balance checks and easy availability of airtime as benefits at all.

The level of customer satisfaction varied enormously amongst cellphone network providers, ranging from $62.6 \%$ for Vodacom to only $4.9 \%$ for 8.ta (Table 2). This is because 8. ta is only a newcomer to the cellphone industry, while Vodacom is already well established. Interestingly, MTN, which has the largest market share in the industry, has the second lowest level of satisfaction, suggesting that customer defection could threaten the viability of this company.

Table 2: Number and percentage of respondents who are satisfied with their networks

\begin{tabular}{lcc}
\hline Network provider & Number of respondents who are satisfied & $\%$ of total \\
\hline Vodacom & 296 & 62.6 \\
MTN & 74 & 15.6 \\
Cell C & 77 & 16.3 \\
Virgin mobile & 103 & 21.8 \\
8s.ta & 23 & 4.9 \\
\hline $\mathrm{N}=429$ & &
\end{tabular}

The relationship between businesses and their customers is the linchpin of business viability. When asked which best methods could be adopted by cellphone network providers to maintain an amicable relationship with their customers, the majority of respondents considered the quality of service and customer satisfaction as the best methods, as shown in Table 3. The highest number of respondents singled out quality of service and customer satisfaction as the most critical factors that affect the quality of the business-customer relationship.

Table 3: Respondents who reported satisfaction with network provider

\begin{tabular}{lcc}
\hline Network provider & Number of respondents who are satisfied & $\%$ of total \\
\hline Service quality & 306 & $64.7 \%$ \\
Customer satisfaction & 253 & $53.5 \%$ \\
Incentives & 93 & $19.7 \%$ \\
Inform customers about new product development & 134 & $28.3 \%$ \\
Lower their switching costs & 77 & $16.3 \%$ \\
Visit customers to find out whether the network is & 76 & $16.1 \%$ \\
performing as promised & 69 & $14.6 \%$ \\
Learning about the culture of customers & 171 & $36.2 \%$ \\
Reasonable prices & 111 & $23.5 \%$ \\
Handling complaint & &
\end{tabular}

However, as shown in Table 3, customers are sensitive to prices, since a significant proportion of the respondents consider reasonable prices as an important factor in determining favourable customer relationships. By charging high prices networks might induce their customers to switch to their competitors, particularly where customers do not have a steady source of income.

The results from ANOVA are presented in Table 4. As noted in Table 4, with respect to effectiveness of advertisements done by different network providers, at 95\% confidence interval $(p=0.05)$, significant differences exist 
between the perceptions held by customers of different networks. Similarly, at $90 \%(p=0.1)$, the perceptions held by the customers of different network providers are significantly different with respect to the handling of queries and costs incurred when customers switch from one network to another. It can be argued that apart from these differences there is homogeneity in the perceptions that are held by the customers of the cellphone networks that operate in the Eastern Free State.

Table 5: ANOVA results

\begin{tabular}{|c|c|c|c|c|c|c|c|c|}
\hline \multirow{2}{*}{ Question } & \multirow{2}{*}{ Parameter } & \multicolumn{4}{|c|}{ Network selected (Q16) } & \multicolumn{3}{|c|}{ ANOVA results } \\
\hline & & Vodacom & MTN & Cell C & Virgin mobile & DF & F Value & $\operatorname{Pr}>\mathrm{F}$ \\
\hline \multirow{2}{*}{ Question 17} & Mean & 3.150 & 3.197 & 3.063 & 3.053 & \multirow{2}{*}{$(3,418)$} & \multirow{2}{*}{0.840} & \multirow{2}{*}{0.474} \\
\hline & Std Dev (n) & $0.484(153)$ & $0.602(218)$ & $0.619(32)$ & $0.848(19)$ & & & \\
\hline \multirow{2}{*}{ Question 18} & Mean & 3.188 & 3.257 & 3.156 & 2.895 & \multirow{2}{*}{$(3,419)$} & \multirow{2}{*}{2.110} & \multirow{2}{*}{$0.098^{*}$} \\
\hline & Std Dev (n) & $0.557(154)$ & $0.678(218)$ & $0.515(32)$ & 0.809 (19) & & & \\
\hline \multirow{2}{*}{ Question 19} & Mean & 3.078 & 3.206 & 3.129 & 2.947 & \multirow{2}{*}{$(3,417)$} & \multirow{2}{*}{1.910} & \multirow{2}{*}{0.127} \\
\hline & Std Dev (n) & $0.58(153)$ & $0.643(218)$ & $0.428(31)$ & $0.97(19)$ & & & \\
\hline \multirow{2}{*}{ Question 20} & Mean & 3.162 & 3.092 & 3.125 & 3.000 & \multirow{2}{*}{$(3,418)$} & \multirow{2}{*}{0.640} & \multirow{2}{*}{0.588} \\
\hline & Std Dev (n) & $0.588(154)$ & $0.602(217)$ & $0.554(32)$ & $0.882(19)$ & & & \\
\hline \multirow{2}{*}{ Question 21} & Mean & 3.163 & 3.128 & 3.156 & 3.105 & \multirow{2}{*}{$(3,418)$} & \multirow{2}{*}{0.120} & \multirow{2}{*}{0.948} \\
\hline & Std Dev (n) & $0.59(153)$ & $0.66(218)$ & $0.448(32)$ & $0.737(19)$ & & & \\
\hline \multirow{2}{*}{ Question 22} & Mean & 2.935 & 2.930 & 2.833 & 2.947 & \multirow{2}{*}{$(3,412)$} & \multirow{2}{*}{0.200} & \multirow{2}{*}{0.893} \\
\hline & Std Dev (n) & $0.666(153)$ & $0.664(214)$ & $0.592(30)$ & $0.97(19)$ & & & \\
\hline \multirow{2}{*}{ Question 26} & Mean & 3.097 & 3.119 & 3.094 & 2.789 & \multirow{2}{*}{$(3,419)$} & \multirow{2}{*}{1.640} & \multirow{2}{*}{0.180} \\
\hline & Std Dev (n) & 0.569 (154) & $0.633(218)$ & $0.466(32)$ & $1.032(19)$ & & & \\
\hline & Mean & 3.148 & 3.169 & 3.125 & 2.889 & & & \\
\hline Question 21 & Std Dev (n) & $0.494(155)$ & $0.593(219)$ & $0.492(32)$ & $0.963(18)$ & $(3,420)$ & 1.340 & 0.260 \\
\hline & Mean & 3.007 & 3.023 & 2.933 & 2.722 & & & \\
\hline Question 28 & Std Dev (n) & 0.407 (152) & $0.404(215)$ & $0.365(30)$ & $0.575(18)$ & $(3,411)$ & 3.240 & $0.022^{\pi x}$ \\
\hline & Mean & 3.113 & 3.075 & 3.167 & 2.833 & & & \\
\hline Question 29 & Std Dev (n) & $0.512(150)$ & $0.546(212)$ & $0.531(30)$ & 0.985 (18) & Ub) & 1.580 & 0.193 \\
\hline & Mean & 1.252 & 1.215 & 1.094 & 0.842 & & 1960 & 0120 \\
\hline Question 31 & Std Dev (n) & $0.778(155)$ & $0.745(219)$ & $0.641(32)$ & $0.602(19)$ & $(3,421)$ & 1.960 & 0.120 \\
\hline Ouestion 34 & Mean & 2.340 & 2.105 & 2.231 & 2.412 & & 2450 & 0 \\
\hline Question 34 & Std Dev (n) & 0.827 (141) & 0.864 (191) & $0.815(26)$ & $0.712(17)$ & (1) & 2.450 & 0.003 \\
\hline
\end{tabular}

* Significant at the 0.1 level ** Significant at the 0.05 levelAnother important issue that was revealed by this study is that access to information about products plays a central role in customer retention. When asked about where they learnt about the cellphone network they used, the majority of the respondents indicated that they got information about their network from television (Table 5), even though many respondents got this information from more than one source.

Table 5: Number of respondents who got information about their network from different media

\begin{tabular}{lcc}
\hline Media & \% of respondents who got information about their network from media & $\%$ of total \\
\hline Television & 341 & $72.1 \%$ \\
Newspaper & 112 & $23.7 \%$ \\
Radio & 147 & $31.1 \%$ \\
Billboards & 69 & $14.6 \%$ \\
Internet & 42 & $8.9 \%$ \\
\hline
\end{tabular}

There is a close relationship between the number of respondents who got information about their networks from specific media types and the number of respondents who have regular access to those media, with a correlation coefficient of 0.98. Two main conclusions can be drawn from this relationship. First, television is the dominant media from which cellphone customers get information about their networks. This suggests that cellphone network providers in South Africa would be most effective in reaching the target market by using television and radio for advertising. Consequently, any information that is meant to enhance customer retention should be advertised through these media. Second, internet is the least accessible, and therefore the least effective media for advertising information that is meant to enhance customer 
retention. Unlike television and radio, that are normally household based media, access to internet is individually based and only those who have a stable source of income use it. Overall, electronic media is more effective in disseminating information for customer retention than other media.

\section{Discussion}

This research study reveals that cellphone network companies in South Africa provide their customers with a number of "benefits" in order to retain them. These include cellphone banking, talking points, bulk purchases, call backs, balance checks and availability of airtime. The results of this study indicate that for cellphone networks to determine if their customer retention strategies are effective they need to check if these strategies are appreciated by their customers. For instance, cellphone networks that are spending money on improving balance check facilities might shift their future investments to cellphone banking because balance checks are not really viewed as a benefit by cellphone users. Thus, cellphone network providers need to fully explore the benefits and setbacks of individual retention strategies. The results also demonstrate that out of the six benefits explored and tested only two are the most viable in retaining customers.

The perceptions held by customers about the quality service offered by cellphone networks are hardly influenced by the benefits that cellphone companies purport to offer. This means that in the cellphone industry investing in the provision of these benefits may not directly add value to customer retention. However, customer retention remains an important element of business performance in the industry. Lombard (2009:72) argues that nowadays the organisation sees customers as valuable assets rather than just sources of revenue that need to be nurtured and protected for exploitation. Perception plays an important role in determining the value that customers attach to the services rendered by players in the cellphone industry. Perception is the process by which an individual selects, organizes, and interprets the information he or she receives from the environment (Sheth and Mittal, 2004:129).

Findings from this study demonstrate that customers' perceptions are central to the valuation of benefits provided by the cellphone companies, indicating that service experience is a subjective personal reaction that is based on the feelings that are felt by customers when consuming or using a service (Chen and Chen, 2009:2). Cook (2000:5) posits that every service experienced is send into the mind of a customer, while Petzer et al, (2009:281) warns that service failure leads to a negative customer experience, which in turn results in an unfavourable perception of the organisation by the customer. The customer's perception of quality has a significant influence on the perception of value (Terblanche and Boshoff, 2010:2). Since customers perceive service quality through every aspect of their contact with the company, attention should also be paid to the service delivery system (Payne et al., 1995:183). However, customers can still defect even when satisfied. This is due to reasons such as another supplier's marketing competitiveness, or customers being persuaded by friends, or the desire to test something new or mere coincidence (Gummesson, 1999:184). Evidence from this research clearly shows that in the eastern Free State the capacity of cellphone companies to retain customers is based not only on perceived value but also on the company's competitive marketing capacity. Chen and Chen (2009:4) define perceived value as the customer's overall assessment of the utility of a product based on the customer's perception of what is received and what is given. They also argue that a perceived value is a better predictor of repurchase intentions than either satisfaction or quality.

For the perceived value that is associated with the benefits offered by cellphone companies to play a more effective role in customer retention these companies need to focus on the major retention drivers, including service quality, customer service and affordability. As noted above, the established fact that customers are prepared to pay higher prices for quality instead of low prices for compromised quality (Onyeaso et al, 2008:3) may not wholly apply in the eastern Free State, suggesting that the key drivers cited above need to be understood within the context of the prevailing socio-economic environment. Affordability appears to be a more important dynamic than service quality per se. This is due to the fact that the eastern Free State is characterized by some of the poorest regions in the Free State province. This is particularly the case with the Maluti-a-phofung, where Phuthaditjaba is located. The region is characterized by poverty and high unemployment rates, both of which are a setback to customer retention. The fact that about $85 \%$ of the cellphone users, who took part in this study, were unemployed provides a strong case to argue for tariff reduction among cellphone companies.

ANOVA showed that though customers in the eastern Free State generally perceive the services provided by the five different networks to be the same they notice significant differences between the effectiveness of the marketing strategies employed by different service providers. Therefore, in order to retain customers the cellphone networks need to effectively advertise their service and provide customer support services, as well as provide information about the level to which their products are affordable. In this regard, electronic media seem to be more effective than other media. Under these circumstances effective use of advertisement and promotional schemes can enhance customer loyalty and 
customer retention or even win back lapsing customers. Bogomolova (2009:2) suggests that returns on investment will be higher if organisations focus their marketing capabilities on retaining lapsed customers, while Stone et al., (2000:106) point out that customer loyalty is the basis for strengthening the purchasing behaviour and state of mind of frequent customers. Effective marketing strategies can enhance customer loyalty and reduce defection, that is, the transfer of customer's brand loyalty to another supplier (Lovelock and Wright, 1999:125).

\section{Concluding Remarks}

The aim of this research study was to identify the customer retention strategies that are employed by the cellphone network providers in South Africa and to evaluate the effectiveness of the strategies from the viewpoint of the customers. The study explored the benefits and setbacks associated with different customer retention strategies and determined the impacts of these benefits and setbacks on the South African cellular networks with the view to recommend the best strategies that work for the South African cellular industry. A number of important conclusions have emerged from this study. First, findings of the study indicate that though there are many retention strategies that have been adopted by cellphone network providers in South Africa, the most effective are quality of the service provided, provision of customer support services and the capacity of the network to provide the services at an affordable price. Second, as a result of high levels of poverty and unemployment within the eastern Free State, cellphone companies should consider affordability of their products as an option for customer retention. Though provision of quality services and benefits is necessary it is not a sufficient condition for customer retention. Third, it can also be concluded that in the eastern Free State effective customer retention can be better achieved not just by enhancing the quality of the service provided but through effective marketing. ANOVA indicates that in the eastern Free State the perceptions of customers of the five cellphone companies are significantly different regarding the effectiveness of the marketing strategies employed by different service providers.

\section{References}

Ahmad, R. and Buttle, F. (2001). Customer retention: a potentially potent marketing management strategy. Journal of Strategic Marketing. Vol (9): 24-45. (Online), Available:http:// www.tandf.co.uk/journals.

Andreassen, T.W. (1999). What Drives Customer Loyalty with Complaint Resolution. Journal of Service Research. Vol (1), N0. 4: 324332.

Boshoff, C. (2006). A proposed instrument to measure the customer satisfaction of visitors to a theme park. Journal of Management Dynamics. Vol (15), N0.3.

Blery, E., Batistatos, N., Papastratou, E., Perifanos, I., Remoundaki, G. and Retsina, M. (2009). Service quality and customer retention in mobile telephony. Journal of Targeting, Measurement and Analysis for Marketing. Vol. 17, N0.1:27-31.

Cohen, D., Gan, C., Au Yong, H. and Choong, E. (2006). Customer satisfaction: A study of bank customer retention in New Zealand. Discussion Paper N0.109.

Dhurup, M. and Surujlal, J. (2008). Retaining Sport Volunteers: An Exploratory Study of Volunteer Motives. African Journal for Physical, Health Education, Recreation and Dance (AJPHERD). Vol. 14, N0.1:19-35.

Fluss, D. Customer Retention is a priority for Mobile Phone Providers. Available: www-gem.org/eng/content_details.jsp? contentid=2317\&subjected=107. Accessed: 21 October 2010.

Fruchter, G.E. \& Zhang, Z.J. (2004). Dynamic Targeted promotions: A Customer Retention and Acquisition Perspective. Journal of Service Research. Vol (7), N0 1: 3-19.

Gee, R., Coates, G. and Nicholson, M. (2008). Understanding and profitably managing customer loyalty. Journal of Marketing Intelligence and Planning. Vol. 26, N0.4:359-374.

Hakim, C. (2000). Research designs: successful designs for social and economic research. London: Routledge.

Hansemark, O.C. (2004). Customer satisfaction and retention: the experience of individual employees. (online), Available:http://www. emeraldinsight.com/Insight/ViewContentServlet? contentType=Article\&Fi... (Accessed: 16 March 2010) J Serv Res, Vol 5 (3): 196-208.

Igbal, A., Zia, M.H., Bashir, S., Shahzad, K., Aslam, M.W. Antecedents and outcomes of Customer Satisfaction in using Prepaid Cellular Service in Pakistan. (online). Available: http:// www.wbiconpro.com/marketing/503- iqbal, A\% 20\&20 \% others.pdf.

Jahanzeb, S. and Jabeen, S. (2007). Churn management in the telecom industry of Pakistan: A comparative study of Ufone and Telenor. Journal of Database marketing \& Customer Strategy Management. Vol. 14: 120-129. (online). Available: http://www.palgravejournals.com/dmn/journal/v14/n2/full/3250043a.html.

Johnson, R.B. and Onwuegbuize, A.J. Mixed methods Research: A Research Paradigm Whose Time Has Come. Educational Researcher. Vol. 33, N0.7: 14-26.

Khan, M.A. (2010). An empirical Assessment of Service Quality of Cellular Mobile Telephone Operators in Pakistan. Asian Social Science. Vol.6, N0.10. Available: www.ccsenet.org/ass.

Karamura, W., Mela., C.F., Ansari, A., Bodapati. A., Fader.P.,Iyengar. R., Naik. P., Neslin. S., Sun. B., Verhoef. P.C., Wedel. M., Wilcox. 
R. (2005). Choice Models and Customer Relationship Management. Springer Science and Business Media. Netherlands.

Karamura, W., Ansari, A., Bodapati, A., Fader, P., Inyengar, R., Naik, P., Neslin, S., Sun, B., Verhoef, P., Wedel, M. and Wilcox, R. (2005). Choice Models and Customer Relationship Management.

Lombard, M.R. (2009). Customer retention strategies implemented by fast food outlets in the Gauteng, Western Cape, and Kwazulunatal provinces of South Africa-A focus on something fishy, nando's and steers. African Journal of Marketing Management. Vol (1), N0. 2:70-80. Available:http://www.academicjournals.org/ajmm.

New dictionary of social work. 1995. Pretoria: State Printers.

Onyeaso, Godwin, Adalikwu and Chris. (2008). An empirical test of customer retention-perceived quality link: strategic management implications. Journal of Business Strategies. Available:http://www.freelibrary.com/An+empirical+test+of+customer+retention+ perceived. Accessed: 31 October 2010.

Ove C, H. and Albinsson, M. (2004). Customer satisfaction and retention: the experience of individual employees. Managing Service Quality. Vol.14, N0.1:40-57. Available: www.emeraldinsight.com/0960-4529.htm.

Pellegrini, G (2008). Customer defection: a signal for the Spanish Telecom Market. (online). Available: http://www.crm2day.com/ highlights/50580.php. Accessed date: 21 October 2010.

Vatanasombut, B., Antonis, C., Stylianou, C. and Igbaria, M. (2004). How to retain online customers. Vol. 47, No.6. Work in progress supervised by four IS professors. Communication of the ACM. 